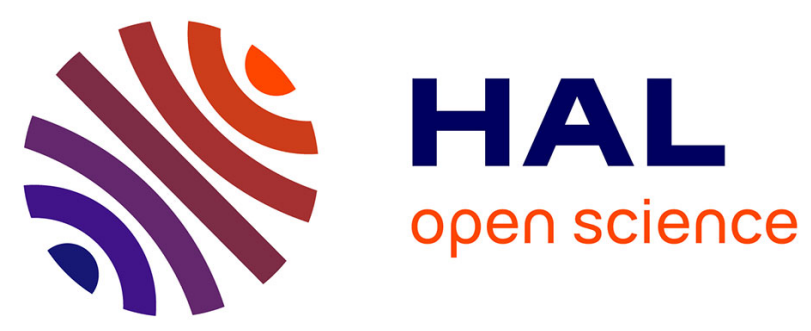

\title{
Long term exposure to environmental concentrations of diesel exhaust particles does not impact the phenotype of human bronchial epithelial cells
}

Camille C Savary, Nessrine Bellamri, Claudie Morzadec, Sophie Langouët, Valérie Lecureur, Laurent Vernhet

\section{To cite this version:}

Camille C Savary, Nessrine Bellamri, Claudie Morzadec, Sophie Langouët, Valérie Lecureur, et al.. Long term exposure to environmental concentrations of diesel exhaust particles does not impact the phenotype of human bronchial epithelial cells. Toxicology in Vitro, 2018, 52, pp.154-160. 10.1016/j.tiv.2018.06.014 . hal-01863793v2

\section{HAL Id: hal-01863793}

https://hal-univ-rennes1.archives-ouvertes.fr/hal-01863793v2

Submitted on 21 Sep 2018

HAL is a multi-disciplinary open access archive for the deposit and dissemination of scientific research documents, whether they are published or not. The documents may come from teaching and research institutions in France or abroad, or from public or private research centers.
L'archive ouverte pluridisciplinaire HAL, est destinée au dépôt et à la diffusion de documents scientifiques de niveau recherche, publiés ou non, émanant des établissements d'enseignement et de recherche français ou étrangers, des laboratoires publics ou privés. 


\section{Long term exposure to environmental concentrations of Diesel exhaust particles does}

not impact the phenotype of human bronchial epithelial cells

Camille C. Savary, Nessrine Bellamri, Claudie Morzadec, Sophie Langouët, Valérie Lecureur and Laurent Vernhet*

Univ Rennes, CHU Rennes, Inserm, EHESP, Irset (Institut de recherche en santé, environnement et travail) - UMR_S 1085, F-35000 Rennes, France

*Corresponding author: Laurent VERNHET, Univ Rennes, CHU Rennes, Inserm, EHESP, Irset (Institut de recherche en santé, environnement et travail) - UMR_S 1085, F-35000 Rennes, France. Phone: 33-2-23-23-48-07; Fax: 33-2-23-23-47-94

E-mail : laurent.vernhet@univ-rennes1.fr

Abbreviations: DEE: diesel engine exhausts, DEP: diesel exhaust particles, PAH: polycylic aromatic hydrocarbons, AhR: aryl hydrocarbon receptor, CYP: cytochrome P450, ROS: reactive oxygen species, B2B: Beas-2B, IL: Interleukin, SRM: Standard Reference Material, DAPI: 4',6-diamidino-2-phenylindole, TGF- $\beta 1$ : Tumor growth factor- $\beta 1$, BEGM: Bronchial epithelial growth medium, $\gamma-\mathrm{H} 2 \mathrm{AX}$ : phospho(ser139)-Histone 2AX, Cq: quantification cycle, DCFH-DA: dichlorodihydrofluorescein-diacetate, DCF: dichlorofluoroscein, MMC: Mitomycin C, NQO1: NADPH quinone oxidoreductase 1, EMT: epithelial-mesenchymal transition, B(a)P: benzo(a)pyrene, BPDE: benzo(a)pyrene-7,8-diol-9,10-epoxide, TNF- $\alpha$ : Tumor Necrosis Factor- $\alpha$ 


\section{Abstract}

Chronic exposure to diesel engine exhausts is associated with an increased risk of pulmonary diseases including lung cancer. Diesel engine exhausts contain large amounts of diesel exhaust particles (DEP) on which are adsorbed several carcinogenic compounds such as polycyclic aromatic hydrocarbons. Acute toxicity of high concentrations of DEP has been largely demonstrated in various in vitro cellular models. In contrast, the cellular and molecular impacts of low environmental concentrations of DEP on the phenotype of chronically exposed lung epithelial cells remain to be investigated. In the present study, we show that long term exposure (6 months) to $2 \mu \mathrm{g} / \mathrm{ml}\left(0.4 \mu \mathrm{g} / \mathrm{cm}^{2}\right)$ DEP (standard reference material 1650b) increased cytochrome P4501A mRNA levels in the human bronchial epithelial BEAS-2B cell line. However, chronic exposure to DEP did not change cell morphology, trigger epithelialmesenchymal transition or increase anchorage-independent cell growth. Moreover, DEP increase neither the levels of reactive oxygen species or those of $\gamma$-histone $\mathrm{H} 2 \mathrm{AX}$, nor the expression of interleukin-6 and interleukin-8. Our results thus demonstrate that the chronic exposure to low DEP concentrations could increase cytochrome P501A gene expression in BEAS-2B cells but did not induce molecular effects related to genotoxicity, oxidative stress or inflammation.

Keywords: diesel exhaust particles, bronchial epithelial cells, toxicity, chronic exposure 


\section{Introduction}

Diesel engine exhausts (DEE) strongly contribute to air pollution in most industrial cities over the world. Chronic exposures to DEE induce irritations of the respiratory tract and can promote the development of respiratory diseases such as asthma, chronic obstructive pulmonary disease and cancers (Steiner et al., 2016). In 2012, based on the results of epidemiological studies, the International Agency for Research on Cancer has concluded that sufficient evidence associate DEE exposure to lung cancer and has thus classified DEE as carcinogenic for humans ("IARC," 2012).

DEE is a complex mixture of gas and diesel exhaust particles (DEP) consisting of an aggregated core of ultrafine and fine carbon particles that are mainly coated with polycyclic aromatic hydrocarbons (PAH) and nitro-PAH (Steiner et al., 2016). Following inhalation, these hydrocarbons can desorb from particles and induce toxicity on the surrounding lung epithelial cells (Gerde et al., 2001). Particularly, the carcinogenic effects of DEP mainly result from the ability of $\mathrm{PAH}$ and nitro-PAH to bind to and activate the arylhydrocarbon receptor (AhR). Once activated, the ligand/AhR complex translocates into the nuclei, dimerizes with the AhR nuclear translocator Arnt and binds to the xenobiotic responsive elements of many gene promoters (Moorthy et al., 2015). AhR activation notably up-regulates the expression of the cytochrome P450 (CYP) $1 \mathrm{~A} 1$ and 1B1, two metabolizing enzymatic complexes which bio-activate PAH and nitro-PAH into electrophilic and genotoxic metabolites (Moorthy et al., 2015). In vivo and in vitro experimental studies suggest that DEP also induce carcinogenic effects by increasing the production of reactive oxygen species (ROS) that cause DNA damages and/or by stimulating the expression of pro-inflammatory cytokines and growth factors in lung epithelial cells (Steiner et al., 2016).

Most in vitro studies reporting the toxic effects of DEP on lung epithelial cells have been performed using short exposures, lasting from $6 \mathrm{~h}$ to $72 \mathrm{~h}$, and DEP concentrations ranging from 10 to $100 \mu \mathrm{g} / \mathrm{ml}$ (approximately 2 to $20 \mu \mathrm{g} / \mathrm{cm}^{2}$ ) (Jardim et al., 2009; Cao et al., 2010; Totlandsdal et al., 2012). Li et al (2003) have calculated that an exposure to ambient particulate matter levels of $79 \mu \mathrm{g} / \mathrm{m}^{3}$ over $24 \mathrm{~h}$ in Rubidoux, a highly polluted site in California, leads to a 
particle mass deposition of 2.3 to $0.05 \mu \mathrm{g} / \mathrm{cm}^{2}$ from tracheobronchial to alveolar regions, respectively (Li et al., 2003). Although it seems very difficult to precisely reconcile in vitro and in vivo particle dosimetry, it thus appears that DEP concentrations used in experimental studies are generally higher than the levels to which humans are exposed. Surprisingly, no in vitro study has assessed the toxicity of low DEP levels on chronically exposed lung epithelial cells. The fact that primary human lung epithelial cells are very difficult to culture probably explains this lack of experimental studies reporting long term toxicity of DEP. By comparing human lung cell models, Courcot et al. (2012) have shown that the human bronchial epithelial BEAS-2B (B2B) cells display the highest homology in gene expression pattern with primary cells. These cells may thus constitute an interesting cell line to assess chemical toxicity (Courcot et al., 2012). B2B cells notably express active AhR and CYP1A1/1B1 proteins and secrete proinflammatory cytokines such as interleukin- (IL-) 6 and IL-8 (Totlandsdal et al., 2012; Le Vee et al., 2016). Different reports demonstrated that high concentrations of DEP can inhibit proliferation, induce DNA adducts and trigger IL-6 and IL-8 expression in B2B cells exposed for short time periods (Pohjola et al., 2003; Cao et al., 2010; Totlandsdal et al., 2012). In addition, B2B cells exposed in vitro for four months to low concentrations of inorganic arsenic, a well-known carcinogenic metalloid, became tumorigenic once injected in nude mice through a mechanism involving ROS production and IL-6 overexpression (Qi et al., 2014). Altogether, these results thus suggest that B2B cells could be an appropriate model to assess the longterm toxicity of environmental DEP concentrations.

The present study was designed to determine if chronic exposure to low DEP levels may alter the phenotype of B2B cells. Our results show that the repeated exposures of B2B cells for 6 months to $2 \mu \mathrm{g} / \mathrm{ml}\left(0.4 \mu \mathrm{g} / \mathrm{cm}^{2}\right)$ DEP (Standard Reference Material 1650b, National Institute of Standards and Technology) significantly increased the expression of CYP1A1 and 1B1 genes but induced neither stable modification of the B2B cell phenotype nor toxic effects related to DNA damage, oxidative stress or inflammation. 


\section{Materials and methods}

\subsection{Chemicals and reagents}

DEP used in the present study was the Standard Reference Material 1650b (SRM 1650b), purchased from the National Institute of Standards and Technology (Gaithersburg,MD, USA). 4',6-diamidino-2-phenylindole (DAPI) and primary antibody (Ab) directed against human phospho(ser139)-Histone H2AX ( $\gamma$-H2AX) were purchased from Cell Signaling Technology (Ozyme, Montigny-le-Bretonneux, France). E-cadherin, N-cadherin and Vimentin Abs were obtained from Santa Cruz Biotechnology (Heidelberg, Germany). Mitomycine C (MMC) and $\mathrm{H}_{2} \mathrm{O}_{2}$ were purchased from Sigma-Aldrich (St-Quentin Fallavier, France). Tumor growth factor$\beta 1$ (TGF- $\beta 1$ ) was obtained from Peprotech (Neuilly-Sur-Seine, France).

\subsection{Cell culture}

B2B cells were obtained from the American Type Culture Collection (CRL-9609). Cells were routinely cultured in complete Bronchial Epithelial Growth Medium (BEGM) (Lonza,Colmar, France) containing bronchial epithelial basal medium supplemented with gentamycin (50 $\mu \mathrm{g} / \mathrm{ml})$, hydrocortisone $(0.5 \mu \mathrm{g} / \mathrm{ml})$, retinoic acid $(0.1 \mathrm{ng} / \mathrm{ml})$, triiodotyronine $(6.5 \mu \mathrm{g} / \mathrm{ml})$, epinephrine $(0.5 \mu \mathrm{g} / \mathrm{ml})$, insulin $(5 \mu \mathrm{g} / \mathrm{ml})$, human EGF $(0.5 \mathrm{ng} / \mathrm{ml})$, transferrin $(10 \mu \mathrm{g} / \mathrm{ml})$ and bovine pituitary extract $(52 \mu \mathrm{g} / \mathrm{ml})$. Cells were cultured at $37^{\circ} \mathrm{C}$ in a humidified atmosphere with $5 \% \mathrm{CO}_{2}$.

\subsection{Preparation of DEP suspension and chronic exposure of B2B cells to DEP}

A SRM 1650b unit consists of $200 \mathrm{mg}$ diesel particulate matter generated by four-cycle diesel engines. This diesel particulate matter contains certified analytical concentrations of $\mathrm{PAH}$ (notably benzo(a)pyrene $(\mathrm{B}(\mathrm{a}) \mathrm{P}$ and phenanthrene) and nitro-PAH (notably 1-nitropyrene and 3-nitrophenanthrene), and induces DNA adducts in B2B cells exposed to high concentrations for $48 \mathrm{~h}$ (Pohjola et al., 2003). A stock suspension $(5 \mathrm{mg} / \mathrm{ml})$ was prepared by suspending DEP in sterile water containing $0.001 \%$ of triton-X100 and sonicating the suspension overnight at room temperature. According to the SRM1650b reference document, the mean particle diameter is $0.18 \mu \mathrm{m}$ after a $24 \mathrm{~h}$ sonication. 
To assess the chronic effects of DEP on B2B cell phenotype, cells were either not expose to DEP for 6 months to get the control passage-matched cell line B-CTR, or exposed to $2 \mu \mathrm{g} / \mathrm{ml}$ $\left(0.4 \mu \mathrm{g} / \mathrm{cm}^{2}\right)$ DEP for six months to generate the B-DEP cell line. At day 1 , cells were seeded at 10000 cells $/ \mathrm{cm}^{2}$ in a $25 \mathrm{~cm}^{2}$ flask and cultured in complete BEGM in the absence or presence of DEP. At day 2 and day 5, the culture medium, with or without DEP, was renewed. At day 7, B-CTR and B-DEP cells were then detached using trypsin and seeded again in a 25 $\mathrm{cm}^{2}$ flask. This procedure was reproduced weekly for both cell lines during the six months. Then, different biological endpoints were compared in recently thawed B2B cells (passage 6 to 10), B-CTR cells and B-DEP cells, that were left untreated or exposed to DEP. To this goal, cells were then washed, detached using trypsin and seeded in the adequate culture plate. The next day, cells were not treated or treated with $2 \mu \mathrm{g} / \mathrm{ml}$ DEP for the indicated time intervals.

\subsection{Soft agar assay}

B-CTR, B-DEP and B2B cells were assessed for transformation by anchorage-independent growth in soft agar medium using the CytoSelect ${ }^{\mathrm{TM}}$ cell transformation assay, according to the manufacturer's protocol (Cell Biolabs, Clinisciences, Nanterre, France). Briefly, a suspension containing 10000 cells were transferred into each well of a 96-well flat-bottom microplate coated with a semisolid agar media and cultured for ten days in complete BEGM medium that did not contain DEP. At the end of the incubation, the cells were lysed after agar dissolution and quantified by the $C y Q u a n t \circledast$ GR Dye using a fluorescence plate reader with excitation at $485 \mathrm{~nm}$ and emission detection at $530 \mathrm{~nm}$. Each independent biological experiment was performed using three technical replicates and each result was the mean of the three replicates.

\subsection{Reverse transcription-quantitative polymerase chain reaction (RT-qPCR) analysis}

Total RNAs were extracted by the TRIzol method and then analyzed by RT-PCR, in duplicate, using the fluorescent dye SYBR Green methodology and a CFX384 real-time PCR system (Bio-Rad, Marns-la-Coquette, France), as previously described (Macoch et al., 2015). Predesigned primers for CYP1A1, CYP1B1, IL-6, and IL-8 gene expression analysis were 
provided by Sigma-Aldrich (St-Quentin Fallavier, France). Specificity of gene amplification was checked at the end of PCR through analysis of dissociation curves of the PCR products. Amplification curves were analyzed by the comparative cycle threshold method, using the CFX Manager ${ }^{\mathrm{TM}}$ Software. For each well, this software automatically sets the fluorescence baseline individually and then computes the optimal quantification cycle $(\mathrm{Cq})$ on a per fluorophore basis by applying a multivariable, nonlinear regression model. Then, mean $\mathrm{Cq}$ values of two technical replicates were used to normalize expression of the steady-state target mRNA levels to those of the $18 \mathrm{~S}$ ribosomal protein, using the $2(-\Delta \Delta \mathrm{Cq})$ method.

\subsection{Western blot analysis}

After treatments, cells were harvested and lysed for 20 min on ice in RIPA buffer supplemented with $1 \mathrm{mM}$ phenylmethylsulfonyl fluoride, $0.5 \mathrm{mM}$ dithiothreitol, $1 \mathrm{mM}$ orthovanadate, and a cocktail of protein inhibitors (Roche Diagnostic, Meylan, France). Cells were then centrifuged at $13000 \mathrm{~g}$ for $15 \mathrm{~min}$ at $4^{\circ} \mathrm{C}$. The resulting supernatants were collected and frozen at $80^{\circ} \mathrm{C}$ or used immediately. Whole cell lysates were heated for $5 \mathrm{~min}$ at $95^{\circ} \mathrm{C}$, loaded in a $4 \%$ stacking gel, and then separated by a $10 \%$ sodium dodecyl sulfate polymerase gel electrophoresis. Gels were electroblotted overnight onto nitro-cellulose membranes (BioRad). After blocking with a Tris-buffered saline solution supplemented with $0.1 \%$ Tween20 and $5 \%$ bovine serum albumin, the membranes were hybridized with primary Abs overnight at $4^{\circ} \mathrm{C}$ and incubated with appropriate secondary horse-radish peroxidase-conjugated Abs. Immunolabeled proteins were visualized by chemiluminescence. Densitometry analyses were carried out by normalizing levels of the target protein expression to those of p38-kinase expression.

\subsection{Measurement of intracellular ROS levels}

The intracellular ROS levels were determined using the dichlorodihydrofluoresceindiacetate (DCFH-DA) dye (Life Technology, Thermo Fischer Scientific, Courtaboeuf, France). Cells were seeded at 50000 cells $/ \mathrm{cm}^{2}$ in a 96-well culture plate and then incubated with 10 $\mu \mathrm{M}$ DCFH-DA for $30 \mathrm{~min}$ at $37^{\circ} \mathrm{C}$. After incubation, cells were washed and DCF fluorescence 
intensity was measured using a Polar Star Omega fluorimeter (BMG LABTECH, Ozyme, SaintQuentin-en-Yveline, France). $\mathrm{H}_{2} \mathrm{O}_{2}$ was used as a positive control to oxidize intracellular DCFH dye. Each independent biological experiment was performed using four technical replicates and each result was the mean of the four replicates.

\subsection{Quantification of $\gamma$-H2AX histone foci by Immunofluorescence}

Analysis of $\gamma-\mathrm{H} 2 \mathrm{AX}$ foci was used to identify DNA double-strand breaks induced by DEP. Double-strand breaks are particularly hazardous as they can lead to genome rearrangements following deficient DNA repair and result in cell death or cancer. $\mathrm{H} 2 \mathrm{AX}$ mediates cell cycle arrest and DNA repair following double-strands DNA breaks. It is activated by phosphorylation on its serine residue 139 (to form $\gamma-\mathrm{H} 2 \mathrm{AX}$ ) at site of DNA damage (Kuo and Yang, 2008). Briefly, B2B, B-CTR and B-DEP cells were seeded at $40000 \mathrm{cells} / \mathrm{cm}^{2}$ in 96 -well culture plate. After washing, the cells were fixed in $4 \%$ paraformaldehyde for $10 \mathrm{~min}$ at room temperature and permeabilized with PBS $0.2 \%$ triton-X100 for $10 \mathrm{~min}$. Cells were washed three times with PBS, stained with primary Ab directed against $\gamma-\mathrm{H} 2 \mathrm{AX}$ overnight at $4^{\circ} \mathrm{C}$ and then incubated with Alexa-647-conjugated IgG for $1 \mathrm{~h}$. Nuclei were counterstained with DAPI and images were then acquired on an ArrayScan VTI high content screening reader with a 320 lens (Thermo Fischer Scientific, Courtaboeuf, France). The images were analyzed using the Cell Profiler software (http://www.cellprofiler.org, Broad Institute). In brief, spots corresponding to focal accumulations of $\gamma-\mathrm{H} 2 \mathrm{AX}$ were detected in B2B, B-CTR, B-DEP cells treated or not with 2 $\mu \mathrm{g} / \mathrm{ml}$ DEP for $24 \mathrm{~h}$. For all analyses, the total amount of DAPI fluorescence and the total amount of Ab fluorescence per nucleus were indicated for each cell. MMC (100-500 $\mu \mathrm{g} / \mathrm{ml})$ was used as a positive control to induce DNA double-strand breaks and subsequent H2AX histone phosphorylation on its serine 139. Each independent biological experiment was performed using four technical replicates and each result was the mean of the four replicates.

\subsection{Statistic analysis}

Data were expressed as mean \pm standard deviation $(S D)$ of the indicated number of independent biological experiments. Significant differences were evaluated using Student's t- 
test or ANOVA followed by the multi-range Dunett's $t$ test when multiple comparisons were studied. Criterion of significance of the difference between means was $p<0.05$.

\section{Results}

\subsection{Determination of the relevant DEP concentration used for chronic B2B cell exposure}

Many biological effects of DEP are mediated through activation of AhR and the subsequent induction of CYP1-metabolizing enzymes. Thus, to determine the concentration of DEP to be used to chronically expose B2B cells, we first determined the lowest concentration that could significantly increase CYP1A1 mRNA levels in B2B cells. To this purpose, cells were treated for $24 \mathrm{~h}$ with 0.1 to $5 \mu \mathrm{g} / \mathrm{ml}\left(0.02\right.$ to $\left.1 \mu \mathrm{g} / \mathrm{cm}^{2}\right)$ DEP. As explained above, these concentrations constitute relevant environmental doses to which human bronchial epithelial cells may be exposed ( $\mathrm{Li}$ et al, 2003). Figure $1 \mathrm{~A}$ shows that the $2 \mu \mathrm{g} / \mathrm{ml}$ DEP concentration was the lowest concentration increasing CYP1A1 mRNA levels. Maximal induction was measured in cells treated with $5 \mu \mathrm{g} / \mathrm{ml}$ DEP. We next determined if CYP1A1 mRNA levels were still induced when B2B cells were cultured for 6 days with $2 \mu \mathrm{g} / \mathrm{ml}$ DEP. As indicated in the Figure 1B, CYP1A1 mRNA levels were indeed significantly enhanced at day 6 . Based on these data, we selected $2 \mu \mathrm{g} / \mathrm{ml}$ DEP to chronically expose B2B cells. Cells were treated for 6 months, as described in the Materials and Methods. Cells chronically treated with DEP were named B-DEP cells whereas their control passage-matched cells (24 to 28 passages) were named B-CTR cells. In addition, B2B cells refer to cells that were cultured in the absence of DEP for a maximum of 6 to 10 passages.

\subsection{Basal and DEP-induced CYP1 mRNA levels are similar in B2B, B-CTR and B-DEP cells}

In the next steps of this study, we investigated stable modifications of the phenotype of cells chronically exposed to $2 \mu \mathrm{g} / \mathrm{ml}$ DEP. In order to avoid characterization of the effects induced by the latest DEP treatments performed during chronic exposure, cells were washed three times, detached and seeded in new culture plates. The next day, B2B, B-CTR and B-DEP cells were left untreated or treated for 6 days with $2 \mu \mathrm{g} / \mathrm{ml} \mathrm{DEP.} \mathrm{After} 6$ days, basal CYP1A1 and CYP1B1 mRNA levels were similar in the three cell lines (Figure 2A). Figure 2B clearly shows 
that CYP1A1/1B1 mRNA levels were significantly increased, with a similar intensity, in B2B, B-CTR and B-DEP cells treated for 6 days with $2 \mu \mathrm{g} / \mathrm{ml} \mathrm{DEP} \mathrm{(Figure} \mathrm{2B).} \mathrm{Thus,} \mathrm{chronic} \mathrm{DEP}$ exposure did not impact the ability of DEP to induce CYP1 gene expression in B2B cells.

\subsection{Chronic DEP exposure does not modify the phenotype of B2B cells}

We next investigated if long term culture in the presence of DEP could affect cell morphology, induce epithelial-mesenchymal transition (EMT) and/or stimulate anchorageindependent cell growth. First, the Figure 3A shows that chronic DEP exposure did not modify the morphology of B2B cells that remained cuboid. We assessed the ability of DEP to induce EMT or to promote TGF- $\beta 1$-induced EMT by measuring protein levels of typical epithelial (Ecadherin) and mesenchymal ( $\mathrm{N}$-cadherin and vimentin) biomarkers. Cells were washed, detached and seeded in new culture plates. The next day, cells were left untreated or stimulated with $10 \mathrm{ng} / \mathrm{ml}$ TGF- $\beta 1$, in the absence of DEP, for four days. Figure 3B shows that basal E-cadherin, $\mathrm{N}$-cadherin and vimentin protein levels remained similar in B2B, B-CTR and B-DEP cells. As expected, TGF- $\beta 1$ stimulation strongly repressed E-cadherin expression and significantly induced those of $\mathrm{N}$-cadherin and vimentin. Chronic exposure of B2B cells to DEP neither prevented nor increased EMT induced by TGF- $\beta 1$. It can be noted however that, although TGF- $\beta 1$ significantly increased $\mathrm{N}$-cadherin and vimentin expressions in B-CTR cells, it only weakly repressed E-cadherin expression. This suggests that long term culture of B2B cells, in the absence of DEP, could have modified TGF- $\beta 1$ signaling. B2B cells are not tumorigenic in immunocompromised mice but did form colonies in semisolid agar medium (Qi et al., 2014). Indeed, we found that B2B cells markedly proliferated when cultured for 10 days in agar semisolid medium. However, at day 10, the numbers of cells measured for the three cell lines remained similar, which suggests that chronic DEP exposure did not amplify the anchorage-independent growth of B2B cells (Figure 3C).

\subsection{Impact of chronic DEP exposure on ROS production, $\gamma-H 2 A X$ levels and pro-inflammatory} gene expression 
Because ROS production, genotoxicity and inflammation are potent molecular mechanisms by which DEP could exert their toxicity, we next analyzed different endpoints associated with these mechanisms of action in B2B, B-CTR and B-DEP cells.

ROS levels were analyzed by quantifying DCF fluorescence in cells seeded in new culture plates and, the next day, left untreated or treated with $2 \mu \mathrm{g} / \mathrm{ml}$ DEP for $24 \mathrm{~h}$. Basal ROS production was identical in B2B, B-CTR and B-DEP cells and was not increased in any cell lines treated with $2 \mu \mathrm{g} / \mathrm{ml} \mathrm{DEP}$ (Figure $4 \mathrm{~A}$ ). Cell treatment, with $2 \mu \mathrm{g} / \mathrm{ml}$ DEP for only $1 \mathrm{~h}$ or 6 $\mathrm{h}$, did not modified ROS levels as well (data not shown). In contrast, basal fluorescence intensity measured in B2B cells (1615 \pm 63.3 relative fluorescence units) was markedly increased by $1 \mathrm{~h}$ stimulation with $\mathrm{H}_{2} \mathrm{O}_{2}$, used as a positive control, and reached $58568 \pm 14931$ relative fluorescence unit, which confirm the sensitivity of B2B cells to ROS. In addition, we measured mRNA levels of NADPH quinone oxidoreductase 1 (NQO1) gene which are generally increased in response to oxidative cell stress and/or ROS production. Figure 4B shows that NQO1 mRNA levels were similar in B2B, B-CTR and B-DEP cells and, thus, not modified by the chronic DEP exposure. We next assessed the ability of DEP to induce DNA double-strand breaks by measuring the intensity of nuclear foci of $\gamma-\mathrm{H} 2 \mathrm{AX}$. Figure $4 \mathrm{C}$ (left panel) clearly demonstrates that MMC, used as a positive control, strongly and significantly increased the formation of $\gamma-\mathrm{H} 2 \mathrm{AX}$ foci in B2B cells treated for $24 \mathrm{~h}$. However, $\gamma-\mathrm{H} 2 \mathrm{AX}$ foci remained identical in B-CTR and B-DEP cells indicating that the chronic DEP treatment did not induce DNA double-strand breaks (Figure 4C, right panel).

Finally, we determined if DEP could up-regulate expression of pro-inflammatory genes in chronically exposed B2B cells. To this goal, we compared in the three cell lines mRNA levels of IL- 6 and IL-8 genes. Cells were seeded in new plates, and the next day, cells were cultured for $24 \mathrm{~h}$ in the absence or presence of $2 \mu \mathrm{g} / \mathrm{ml}$ DEP. Basal IL-6 and IL-8 mRNA levels were similar in B2B, B-CTR and B-DEP cell lines (Figure 4C). DEP treatment for $24 \mathrm{~h}$ did not modify IL-6 and IL-8 gene expression in any cell lines (data not shown). 


\section{Discussion}

In the present study, we show that chronic exposure of the human bronchial epithelial B2B cells to low environmental concentrations of DEP significantly increased CYP1 gene expressions but did not induce cancer-related modifications of the cell phenotype.

First, our results demonstrate that B-DEP cells, exposed for 6 months to $2 \mu \mathrm{g} / \mathrm{ml}$ DEP, control matched-passage B-CTR cells, and parental B2B cells displayed similar basal and DEP-induced levels of CYP1A1 and CYP1B mRNA. Thus, the chronic exposure to DEP neither permanently increased CYP1 gene expression nor alter the sensitivity of B-DEP cells to a new DEP treatment. Two $\mu \mathrm{g} / \mathrm{ml}\left(0.4 \mu \mathrm{g} / \mathrm{cm}^{2}\right)$ represents the lowest concentration of DEP inducing CYP1A1 expression in B2B cells treated for $24 \mathrm{~h}$. Totlansdal et al. (2015) reported that DEP, generated from a diesel engine different from that producing the SRM 1650b DEP, could significantly increase CYP1A1 mRNA levels in B2B cells, when used at a concentration as low as $0.013 \mu \mathrm{g} / \mathrm{cm}^{2}$. These results indicate that CYP1A1 gene expression is thus a very sensitive endpoint that can be measured to assess the effects of environmental DEP concentrations in B2B cells. However, the expression of CYP1A1 may not constitute a general cell biomarker highlighting DEP exposure since CYP1A1 expression is also induced by many other chemicals.

CYP1A1 gene is specifically induced in response to AhR activation and its expression is probably controlled by AhR agonists desorbed from DEP. In this context, the referent document indicates that SRM 1650b DEP contain several PAH and nitro-PAH such as B(a)P, benzo(a)anthracene, chrysene and nitro-pyrene which are potent AhR agonists. CYP1A1 and 1B1 metabolize these PAH into electrophilic metabolites that mediate their carcinogenic effects. For example, the metabolite of $B(a) P$, benzo(a)pyrene-7,8-diol-9,10-epoxide (BPDE), is cytotoxic, mutagenic and carcinogenic (Moorthy et al., 2015). In B2B cells, this metabolite induces stable expression of cyclin D1 by a mechanism involving a phosphatidylinositol 3kinase/AKT/MAPK pathway. Up-regulation of cyclin D1 plays a major role in oncogenic transformation and tumorigenesis of B2B cells treated with $0.5 \mu \mathrm{M}$ BPDE for 12 weeks (Ding et al., 2009). In addition, chronic treatment of B2B with $1 \mu \mathrm{M}$ BPDE downregulates expression 
of the PHLPP2 phosphatase that leads to sustained Tumor Necrosis Factor $\alpha$ (TNF- $\alpha$ ) gene induction. Besides cyclin D1, up-regulation of TNF- $\alpha$ is critical for B(a)P/BPDE-induced anchorage-independent growth in soft agar and tumorigenesis in mice (Huang et al., 2015). Finally, $\mathrm{B}(\mathrm{a}) \mathrm{P}$ induces the formation of BPDE-DNA adducts and significantly increases the number of micronuclei in B2B cells (van Agen et al., 1997).

Our results show that chronic exposure to $2 \mu \mathrm{g} / \mathrm{ml}$ DEP (SRM 1650b) did not stimulate the ability of B2B cells to proliferate in soft agar medium or increase the formation of $\gamma-\mathrm{H} 2 \mathrm{AX}$ foci. The amounts of PAH or nitro-PAH desorbed from DEP were sufficient to induce CYP1A1 gene expression but were likely too low to generate concentrations of ultimate carcinogenic metabolites able to promote cell transformation or exert mutagenic effects in B2B cells. This idea is supported by the results published by Pohjola et al (2003) which demonstrated that 15 $\mu \mathrm{g} / \mathrm{ml}$ SRM 1650 DEP only slightly increased DNA adducts in B2B cells exposed for $48 \mathrm{~h}$. Similarly, our study indicates that the repeated treatments of B2B cells with $2 \mu \mathrm{g} / \mathrm{ml}$ DEP did not modify ROS levels or IL-6/IL-8 expression. Totlandsdal et al. (2003) reported that 25 to 100 fold higher concentrations $(50-200 \mu \mathrm{g} / \mathrm{ml})$ of DEP were necessary to stimulate IL-6 and IL8 release from B2B cells exposed for $24 \mathrm{~h}$. It is also noteworthy that DEP did not trigger EMT, a major developmental process that favors migration/invasion and metastasis of epithelial cancer cells (Roche et al., 2017). EMT is nevertheless induced in B2B cells chronically exposed to total particulate matter from cigarette smoke that is known to contain carcinogenic PAH such as B(a)P (van der Toorn et al., 2018).

In contrast to DEP, different reports have clearly demonstrated that long term exposure to low concentrations of inorganic arsenic, in the range of plasmatic arsenic levels measured in chronically exposed individuals, promoted tumorigenic transformation of B2B cells by different molecular mechanisms involving sustained ROS levels, up-regulated IL-6 expression and EMT (Zhang et al., 2012; Qi et al., 2014; Yang et al., 2017). B2B cells may thus constitute an adequate in vitro model to investigate molecular mechanisms of some, but not all, carcinogenic chemicals. Particularly, our results show that low environmentally relevant concentrations of 
DEP did not induce cancer-related effects in chronically exposed B2B cells. Moreover, it should be noted that an in vivo experimental study has recently reported that chronic exposure of rats to a high, but realistic, concentration of DEE for periods of $3 \mathrm{~h}$ every day, for 5 days, during 3 weeks, did not modified ROS levels, $\gamma-\mathrm{H} 2 \mathrm{AX}$ foci or induce DNA adducts in lungs (Douki et al., 2018). Moreover, epidemiological studies have shown that the increased risk of human lung cancer associated with occupational exposure to diesel emission is only modest (Möhner and Wendt, 2017). Thus, whatever the cell model used, it must be difficult to highlight the in vitro carcinogenic effects of low environmental concentrations of DEP.

In conclusion, our study demonstrates that DEP similarly increases CYP1A1 expression in the human bronchial epithelial B2B (BEAS-2B) cell line unexposed or exposed for 6 months to environmentally relevant concentrations of DEPs. Moreover, we show that chronic exposure to these low DEP concentrations induces neither molecular mechanism nor phenotype modification related to genotoxic, pro-oxidant or inflammatory effects of DEP. Altogether, these results strongly suggest that the long-term toxicity of the SRM $1650 \mathrm{~b}$ DEP is thus very limited in this cell line. In the future, chronic DEP effects towards human lung cells should be further addressed by assessing in vitro chronic toxicity of DEP collected from more recent engines, using classical 2D and/or newly developed 3D cell models.

\section{Acknowledgments}

This work was funded by the Institut national de la santé et de la recherche médicale (INSERM) and by the Université de Rennes (Univ Rennes). We are grateful to Remy Le Guevel from the ImPACcell platform (SFR UMS CNRS 3480 - INSERM 018, Biosit, Univ Rennes, Rennes, France) for image acquisition and quantification of $\gamma-\mathrm{H} 2 \mathrm{AX}$ foci.

\section{References}

Cao, D., Bromberg, P.A., Samet, J.M., 2010. Diesel particle-induced transcriptional expression of p21 involves activation of EGFR, Src, and Stat3. Am. J. Respir. Cell Mol. Biol. 42, 8895. 
Courcot, E., Leclerc, J., Lafitte, J.-J., Mensier, E., Jaillard, S., Gosset, P., Shirali, P., Pottier, N., Broly, F., Lo-Guidice, J.-M., 2012. Xenobiotic metabolism and disposition in human lung cell models: comparison with in vivo expression profiles. Drug Metab. Dispos. Biol. Fate Chem. 40, 1953-1965.

Ding, J., Ning, B., Gong, W., Wen, W., Wu, K., Liang, J., He, G., Huang, S., Sun, W., Han, T., Huang, L., Cao, G., Wu, M., Xie, W., Wang, H., 2009. Cyclin D1 induction by benzo[a]pyrene-7,8-diol-9,10-epoxide via the phosphatidylinositol 3-kinase/Akt/MAPK- and p70s6k-dependent pathway promotes cell transformation and tumorigenesis. J. Biol. Chem. $284,33311-33319$.

Douki, T., Corbière, C., Preterre, D., Martin, P.J., Lecureur, V., André, V., Landkocz, Y., Pottier, I., Keravec, V., Fardel, O., Moreira-Rebelo, S., Pottier, D., Vendeville, C., Dionnet, F., Gosset, P., Billet, S., Monteil, C., Sichel, F., 2018. Comparative study of diesel and biodiesel exhausts on lung oxidative stress and genotoxicity in rats. Environ. Pollut. 235, 514-524.

Gerde, P., Muggenburg, B.A., Lundborg, M., Dahl, A.R., 2001. The rapid alveolar absorption of diesel soot-adsorbed benzo[a]pyrene: bioavailability, metabolism and dosimetry of an inhaled particle-borne carcinogen. Carcinogenesis 22, 741-749.

Huang, H., Pan, X., Jin, H., Li, Y., Zhang, L., Yang, C., Liu, P., Liu, Y., Chen, L., Li, J., Zhu, J., Zeng, X., Fu, K., Chen, G., Gao, J., Huang, C., 2015. PHLPP2 Downregulation Contributes to Lung Carcinogenesis Following B[a]P/B[a]PDE Exposure. Clin. Cancer Res. Off. J. Am. Assoc. Cancer Res. 21, 3783-3793.

IARC: diesel engine exhaust carcinogenic, 2012. . Cent. Eur. J. Public Health 20, 120, 138. Jardim, M.J., Fry, R.C., Jaspers, I., Dailey, L., Diaz-Sanchez, D., 2009. Disruption of microRNA expression in human airway cells by diesel exhaust particles is linked to tumorigenesisassociated pathways. Environ. Health Perspect. 117, 1745-1751.

Kuo, L.J., Yang, L.-X., 2008. Gamma-H2AX - a novel biomarker for DNA double-strand breaks. Vivo Athens Greece 22, 305-309. 
Le Vée, M., Jouan, E., Lecureur, V., Fardel, O., 2016. Aryl hydrocarbon receptor-dependent up-regulation of the heterodimeric amino acid transporter LAT1 (SLC7A5)/CD98hc (SLC3A2) by diesel exhaust particle extract in human bronchial epithelial cells. Toxicol. Appl. Pharmacol. 290, 74-85.

Li, N., Hao, M., Phalen, R.F., Hinds, W.C., Nel, A.E., 2003. Particulate air pollutants and asthma. A paradigm for the role of oxidative stress in PM-induced adverse health effects. Clin. Immunol. Orlando Fla 109, 250-265.

Möhner, M., Wendt, A., 2017. A critical review of the relationship between occupational exposure to diesel emissions and lung cancer risk. Crit. Rev. Toxicol. 47, 185-224.

Moorthy, B., Chu, C., Carlin, D.J., 2015. Polycyclic aromatic hydrocarbons: from metabolism to lung cancer. Toxicol. Sci. Off. J. Soc. Toxicol. 145, 5-15.

Pohjola, S.K., Lappi, M., Honkanen, M., Rantanen, L., Savela, K., 2003. DNA binding of polycyclic aromatic hydrocarbons in a human bronchial epithelial cell line treated with diesel and gasoline particulate extracts and benzo[a]pyrene. Mutagenesis 18, 429-438.

Qi, Y., Zhang, M., Li, H., Frank, J.A., Dai, L., Liu, H., Zhang, Z., Wang, C., Chen, G., 2014. Autophagy inhibition by sustained overproduction of IL6 contributes to arsenic carcinogenesis. Cancer Res. 74, 3740-3752.

Roche, J., Gemmill, R.M., Drabkin, H.A., 2017. Epigenetic Regulation of the Epithelial to Mesenchymal Transition in Lung Cancer. Cancers 9.

Steiner, S., Bisig, C., Petri-Fink, A., Rothen-Rutishauser, B., 2016. Diesel exhaust: current knowledge of adverse effects and underlying cellular mechanisms. Arch. Toxicol. 90, 15411553.

Totlandsdal, A.I., Herseth, J.I., Bølling, A.K., Kubátová, A., Braun, A., Cochran, R.E., Refsnes, M., Ovrevik, J., Låg, M., 2012. Differential effects of the particle core and organic extract of diesel exhaust particles. Toxicol. Lett. 208, 262-268.

van Agen, B., Maas, L.M., Zwingmann, I.H., Van Schooten, F.J., Kleinjans, J.C., 1997. B[a]PDNA adduct formation and induction of human epithelial lung cell transformation. Environ. Mol. Mutagen. 30, 287-292. 
van der Toorn, M., Sewer, A., Marescotti, D., Johne, S., Baumer, K., Bornand, D., Dulize, R., Merg, C., Corciulo, M., Scotti, E., Pak, C., Leroy, P., Guedj, E., Ivanov, N., Martin, F., Peitsch, M., Hoeng, J., Luettich, K., 2018. The biological effects of long-term exposure of human bronchial epithelial cells to total particulate matter from a candidate modified-risk tobacco product. Toxicol. Vitro Int. J. Publ. Assoc. BIBRA 50, 95-108.

Yang, J., Chen, Z., Wang, X., Xu, M., Fang, H., Li, F., Liu, Y., Jiang, Y., Ding, Y., Li, J., Wang, S., 2017. Inactivation of miR-100 combined with arsenic treatment enhances the malignant transformation of BEAS-2B cells via stimulating epithelial -mesenchymal transition. Cancer Biol. Ther. 18, 965-973.

Zhang, T., Qi, Y., Liao, M., Xu, M., Bower, K.A., Frank, J.A., Shen, H.-M., Luo, J., Shi, X., Chen, G., 2012. Autophagy is a cell self-protective mechanism against arsenic-induced cell transformation. Toxicol. Sci. 130, 298-308. 


\section{Legends}

Figure 1: Induction of CYP1A1 mRNA expression by DEP in B2B cells. Cells were exposed to 0.1 to $5 \mu \mathrm{g} / \mathrm{ml}$ DEP for $24 \mathrm{~h}(\mathrm{~A})$ and to $2 \mu \mathrm{g} / \mathrm{ml}$ DEP for 6 days (B). mRNA levels of CYP1A1 were determined by quantitative RT-PCR and normalized to endogenous ribosomal 18S RNA levels. Data are expressed relatively to mRNA levels found in "0" untreated cells, arbitrarily set at the value of 1 . All results are expressed as means \pm SD of four independent biological experiments. * $p<0.05,{ }^{* * *} p<0.001$ versus " 0 ".

Figure 2: Basal and DEP-induced CYP1A1/CYP1B1 mRNA levels in B2B, B-DEP and BCTR cells. B2B cells (passages 6 to 10 ), B2B cells cultured in the presence of $2 \mu \mathrm{g} / \mathrm{ml}$ DEP for 6 months (B-DEP) and passage-matched B2B cells (B-CTR) were untreated (-) or exposed to $2 \mu \mathrm{g} / \mathrm{ml} \mathrm{DEP} \mathrm{(+)} \mathrm{for} 6$ days, as described in the Materials and Methods section. Then, cells were harvested and total RNA were extracted. CYP1A1 and CYP1B1 mRNA levels were determined by quantitative RT-PCR and normalized to endogenous ribosomal 18S RNA levels. Basal (A) and DEP-induced (B) mRNA levels of CYP1A1 and CYP1B1 in the three cell lines were compared by measuring the respective optimal quantification cycle $(\mathrm{Cq})$ for the two genes (A) or the relative gene induction (B). In (B), data are expressed relatively to mRNA levels measured in the respective untreated cells ("-"), arbitrarily set at the value of 1 . All results are expressed as means $\pm S D$ of four independent biological experiments. ${ }^{*} p<0.05,{ }^{* *} p<0.01$, versus "-".

Figure 3: Morphology and phenotypes of B2B, B-CTR and B-DEP cells. (A) Confluent B2B, B-CTR and B-DEP cells were observed by light microscopic just before their passage. (B) Cells were untreated (-) or stimulated with $10 \mathrm{ng} / \mathrm{ml}$ TGF- $\beta 1$ (+) for four days. Then, cells were harvested and total protein were extracted as described in the Materials and Methods section. Expression of EMT protein markers were determined by Western Blot. The left panel shows a representative Western blot of E-cadherin, $\mathrm{N}$-cadherin and vimentin. Densitometric analysis of protein expression measured in five independent biological experiments is presented in the right panel. (C) Cell proliferation in soft agar assays was assessed after a 10- 
day culture using the CytoSelect cell transformation assay kit, according to the manufacturer's recommendations. Results are expressed as means \pm SD of five (B) and four (C) independent biological experiments. ${ }^{*} p<0.05,{ }^{* *} p<0.01,{ }^{* * *} p<0.001$ versus "-".

Figure 4: ROS, $\gamma$-H2AX levels and pro-inflammatory gene expression in B2B, B-CTR and B-DEP cells. B2B, B-CTR and B-DEP cells were untreated (-) or cultured with $2 \mu \mathrm{g} / \mathrm{ml}$ DEP (+) for 24 h. (A) ROS levels were then determined by measuring intracellular fluorescence of the redox-sensitive DCF dye by microspectrofluorimetry. (B and D) Basal mRNA levels of NQO1 (B), IL-6 and IL-8 (D) genes were determined by quantitative RT-PCR and normalized to endogenous ribosomal $18 \mathrm{~S}$ RNA levels. The mRNA levels were compared by measuring the optimal quantification cycles $(\mathrm{Cq})$ for the three genes. (C) DNA damages were assessed by quantifying $\gamma-\mathrm{H} 2 \mathrm{AX}$ foci by immunofluorescence staining. Positive controls were performed by treating cells for $24 \mathrm{~h}$ with 100 and $500 \mu \mathrm{g} / \mathrm{ml}$ mitomycine $\mathrm{C}(\mathrm{MMC})$. Results are expressed as means $\pm S D$ of three $(A)$ or five $(B-D)$ independent biological experiments. ${ }^{* *} p<0.01$ versus "0". 
A

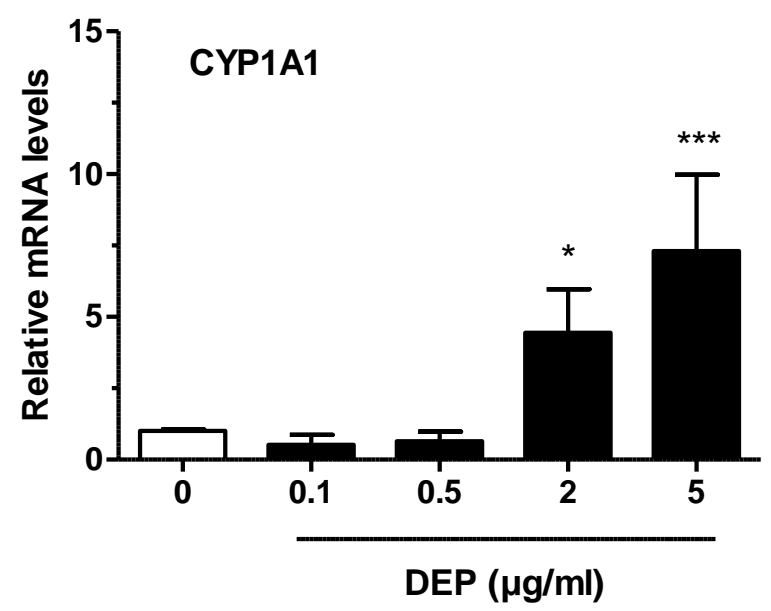

B

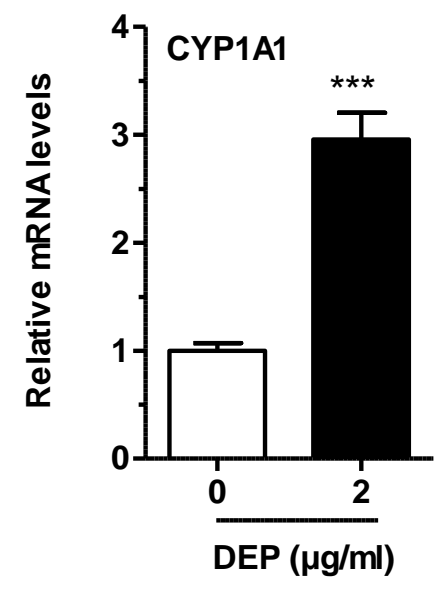


A
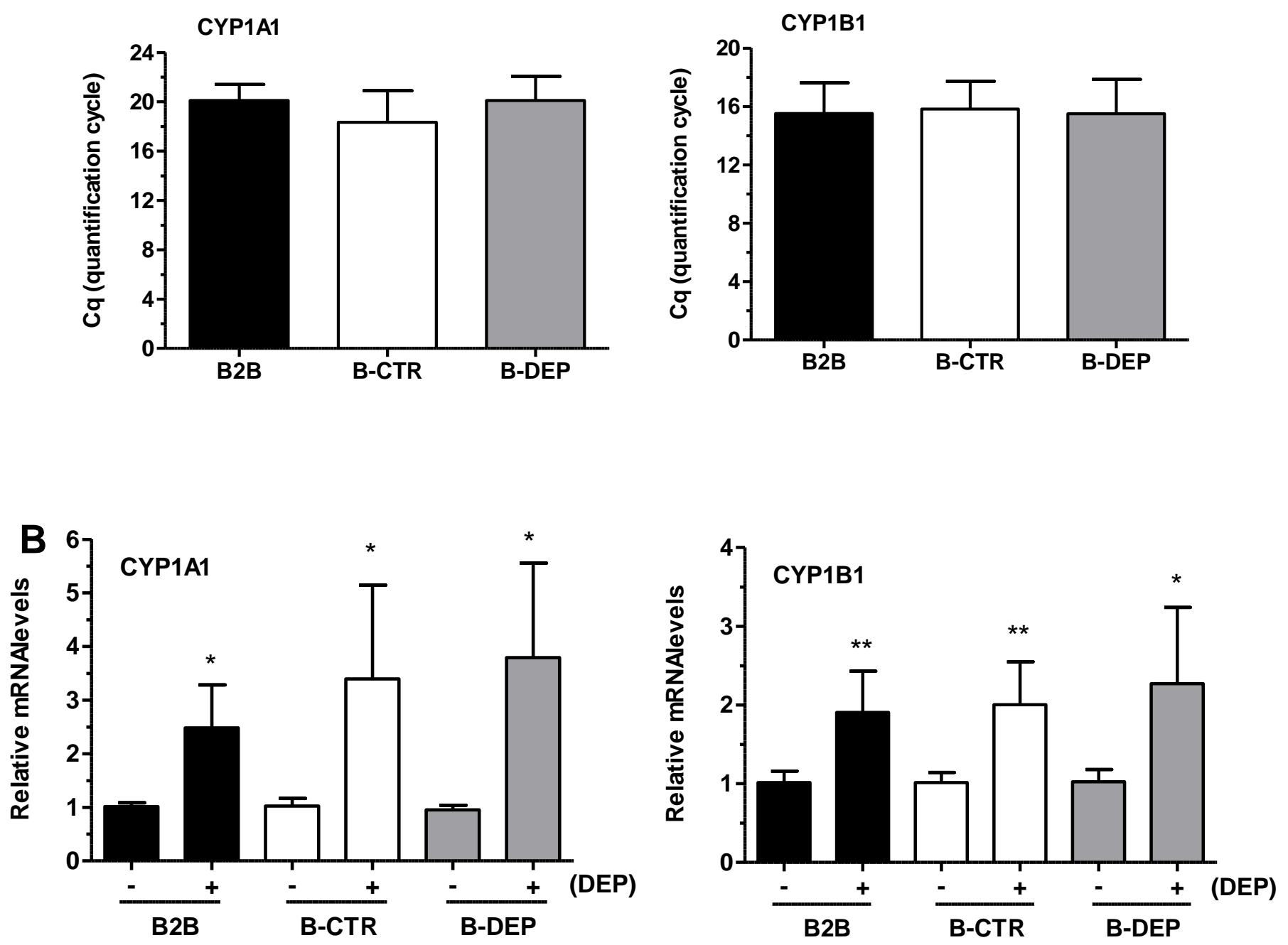

Figure 2 
A
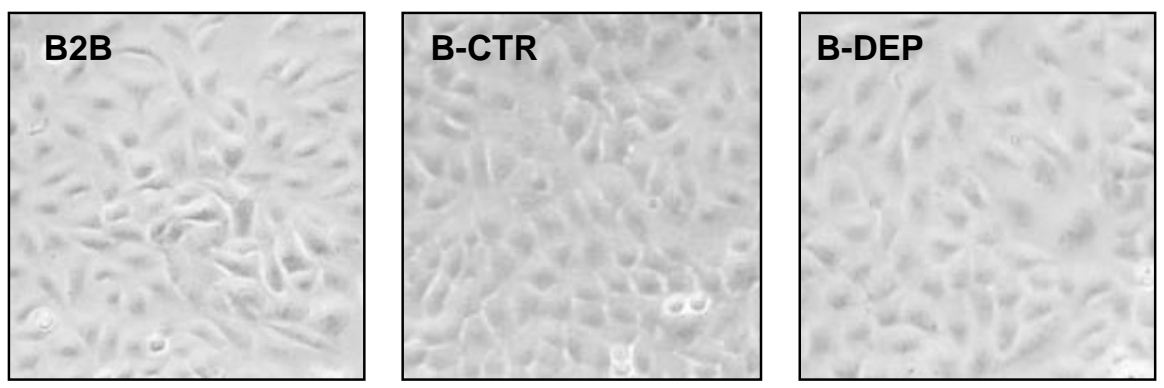

B
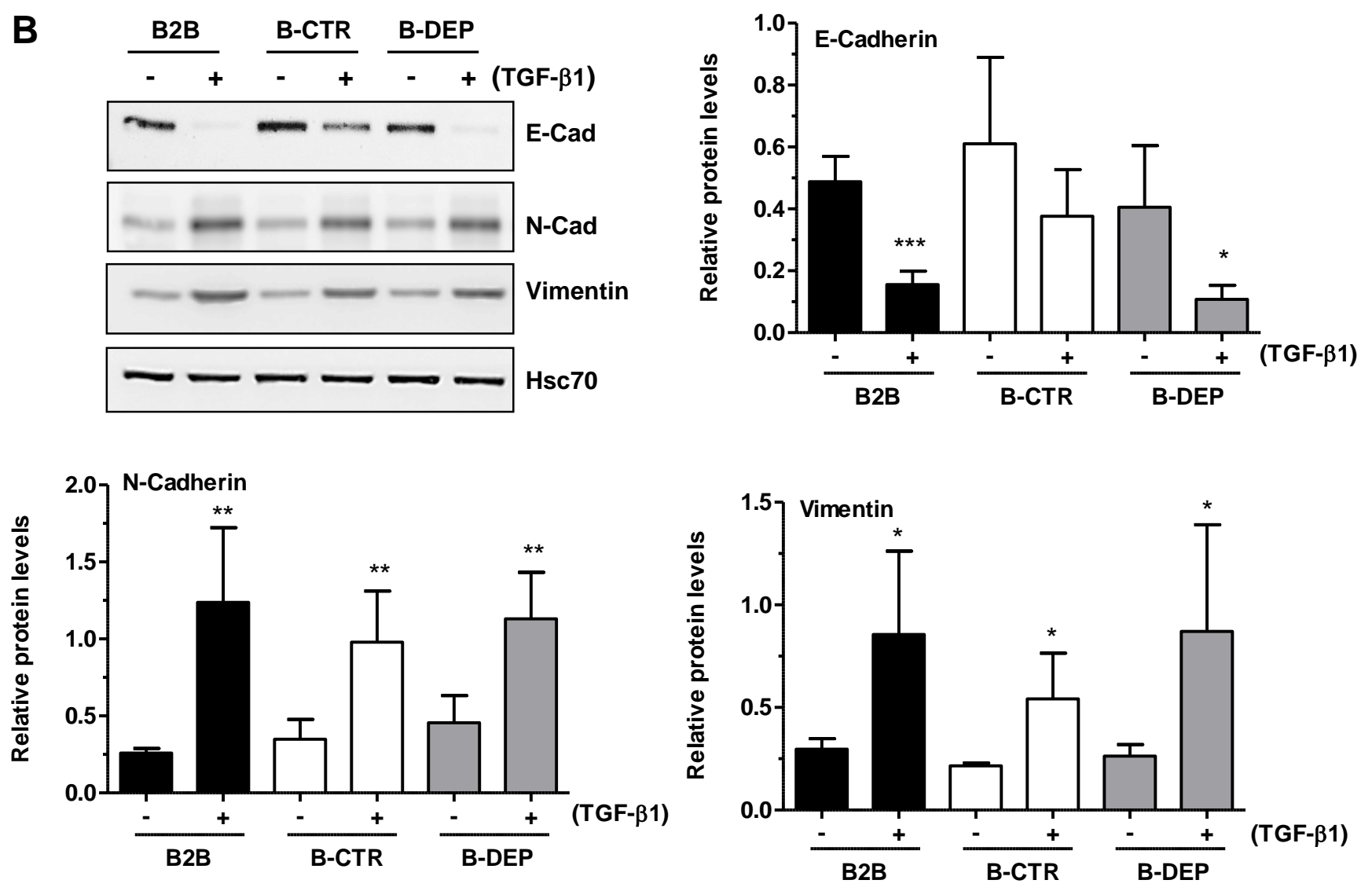

C

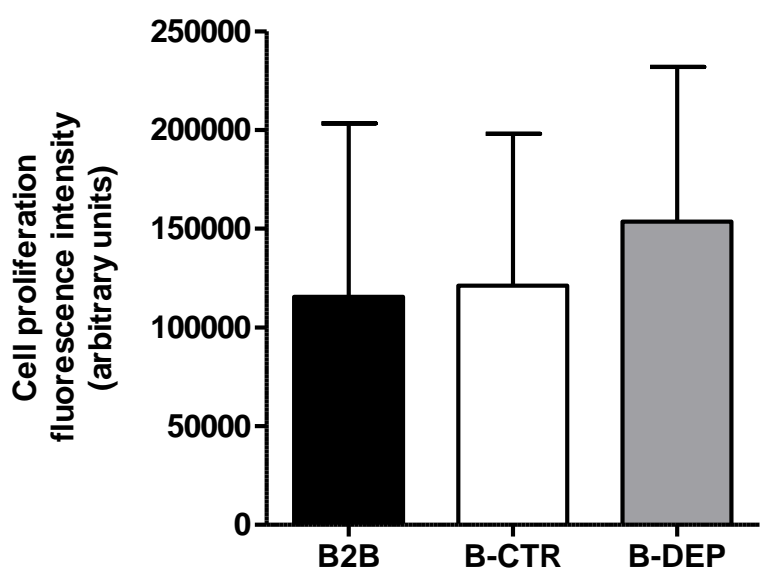

Figure 3 

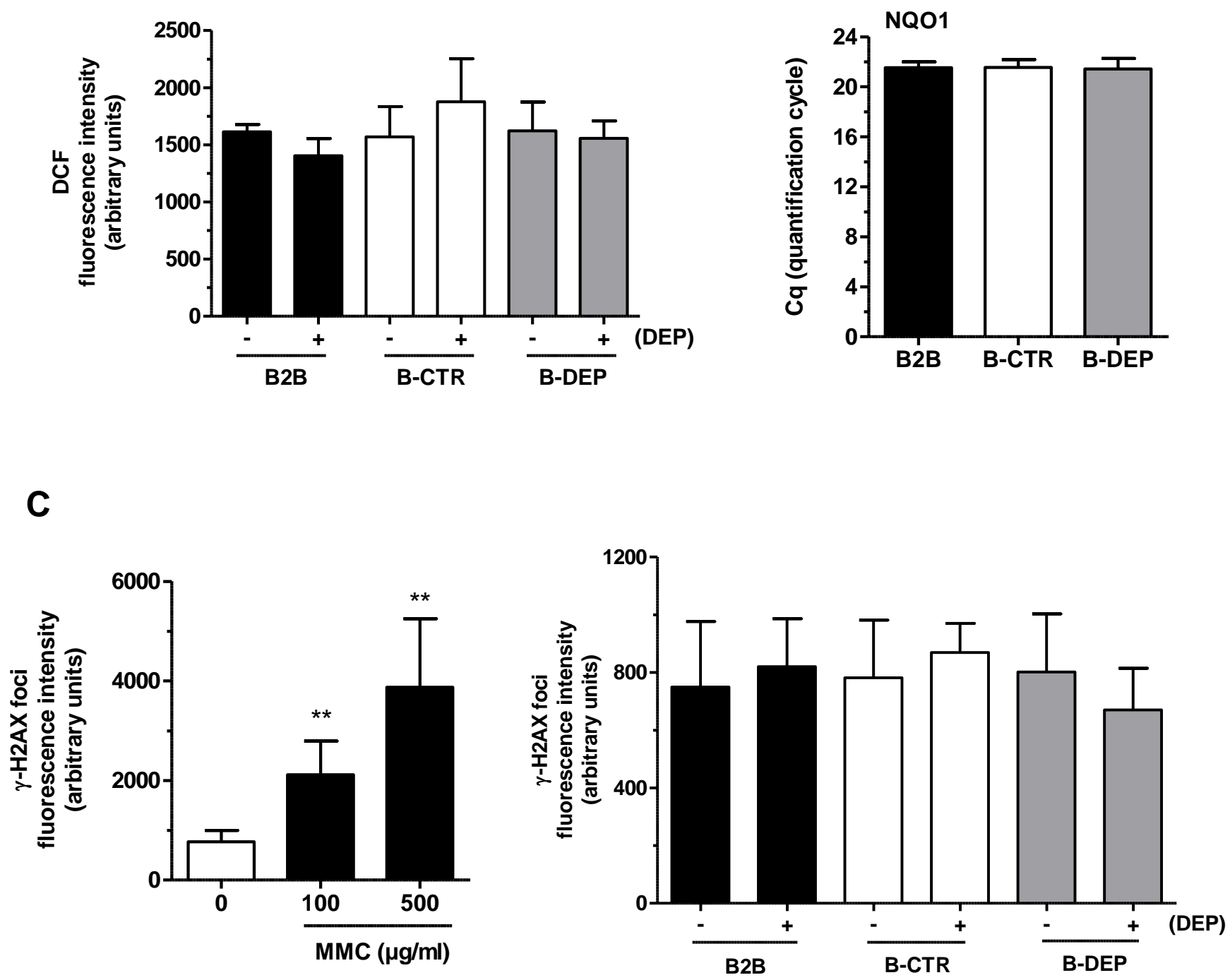

D

IL-6

IL-8
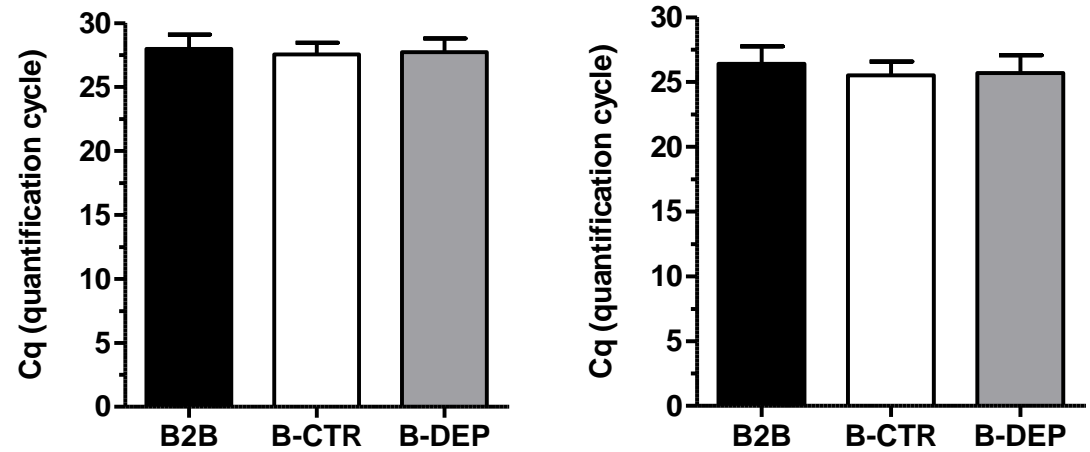